25. Woodroffe, C. D., Development of mangrove forests from a geological perspective. In Biology and Ecology of Mangroves. Tasks for Vegetation Science (ed. Teas, H. J.), Springer, Dordrecht, 1983, p. 1-17; https://doi.org/10.1007/978-94-017-0914-9 1.

26. Mascarenhas, A., Significance of peat on the western continental shelf of India. J. Geol. Soc. India, 1997, 49, 145-152.

27. Pandarinath, K., Shankar, R. and Yadava, M. G., Late Quaternary changes in sea level and sedimentation rate along the SW coast of India: evidence from radiocarbon dates. Curr. Sci., 2001, 81(5), 594-600.

ACKNOWLEDGEMENTS. The authors thank the Director, CSIRNational Institute of Oceanography, Goa for his support, encouragement and permission to publish this work. We thank the entire scientific and technical team and crew onboard Coastal Research Vessel Sagar Sukti and Mechanized Fishing Boat Phalguni for providing their support during data acquisition. Figures were prepared using GMT software of Wessel and Smith (1998). K. M. Dubey acknowledges the University Grants Commission, New Delhi, India for financial support as JRF and SRF. This is CSIR-NIO contribution number 6330.

Received 19 August 2018; revised accepted 27 November 2018

doi: $10.18520 / \mathrm{cs} / \mathrm{v} 116 / \mathrm{i} 8 / 1410-1417$

\section{Carbon sequestration potential of mango orchards in the tropical hot and humid climate of Konkan region, India}

\author{
A. N. Ganeshamurthy*, V. Ravindra, T. R. Rupa \\ and R. M. Bhatt \\ ICAR- Indian Institute of Horticultural Research, \\ Bengaluru 560 089, India
}

Cultivated grafted mangoes are not the same as polyembryonic seedling-based wild mangoes in terms of biomass production and carbon sequestration. We estimated the carbon sequestration potential of mangoes in Konkan region, which is a prime mango belt of India producing the popular Alphonso mangoes. Allometric equation developed for grafted mangoes was used to estimate tree biomass. Konkan mango belt spread over 106,210 ha sequesters $9.913 \mathrm{mt}$ of carbon. However, the carbon sequestration potential of these cultivated grafted mangoes is very low compared to polyembryonic seedling-grown mangoes in the wild. Since mangoes in the Konkan region have mostly occupied degraded lands of lateritic origin, such re-

*For correspondence. (e-mail: angmurthy@gmail.com) gions have been brought under productive mango orchards. As a consequence where forests have disappeared and mangoes have occupied the region, the carbon sequestered by them is a bonus apart from the production of mangoes. The administrators in these regions must use this information for claiming carbon credits for the benefit of farmers and the local population.

Keywords: Carbon sequestration, mango orchards, soil carbon stocks, tree biomass.

THE most dreaded problem of the new millennium caused by the impact of human activity is global warming. Anthropogenic activities like enhanced fossil-fuel consumption coupled with deforestation are causing serious public and political concerns on greenhouse gas (GHG) emissions and their consequences on loss of biodiversity and climate change $\mathrm{e}^{1-4}$. An option for augmenting the emission of GHGs is to enhance the carbon stored in perennial trees through sequestration. Forests sink about $40 \%$ of the global carbon on land ${ }^{5}$. However, perennial orchards, plantations and agro forestry are other alternatives for the trapping of carbon. It is considered that in the Indian context forests, agroforestry and perennial horticultural crops trap a significant amount of carbon emitted through fossil-fuel combustion ${ }^{6}$. The dynamics of this forest carbon has a significant influence on the global carbon budget. Estimates based on global or regional soil carbon densities of various forests shows that Indian forests sequester about 5.3-6.7 Pg C (refs 7, 8). In the present scenario, the forest area is declining while perennial fruit orchards and plantation area are on the increase ${ }^{\text {. }}$.

Generally, during the initial stage of establishment, both orchards and forests sequester similar amounts of carbon. Comparing orchards with forests is not justified as the former have a management component completely anthropogenic, while management of the latter in Asian countries is more towards silviculture and not inputbacked management. Nevertheless, orchards do have the potential similar to forests but on a lower scale because of indirect $\mathrm{C}$ emissions associated with orchard management practices. An estimate of the carbon sequestration potential of fruit orchards in India is therefore essential for any strategic planning, offsetting GHG emissions and for trading carbon.

Mango is the major fruit crop grown throughout India in areas having a distinct dry and wet season. Being an evergreen and deep-rooted (1.0 $\mathrm{m}$ and deeper) tree, it has adopted to fix carbon under large seasonal variation of light and water. Two types of mango population occur in India, the wild polyembryonic mangoes and the cultivated grafted mangoes. Estimates of the population and area occupied by wild polyembryonic mangoes are not available, but surely is a sizable area as India is the origin of mangoes. Cultivated mango occupies an area of nearly 


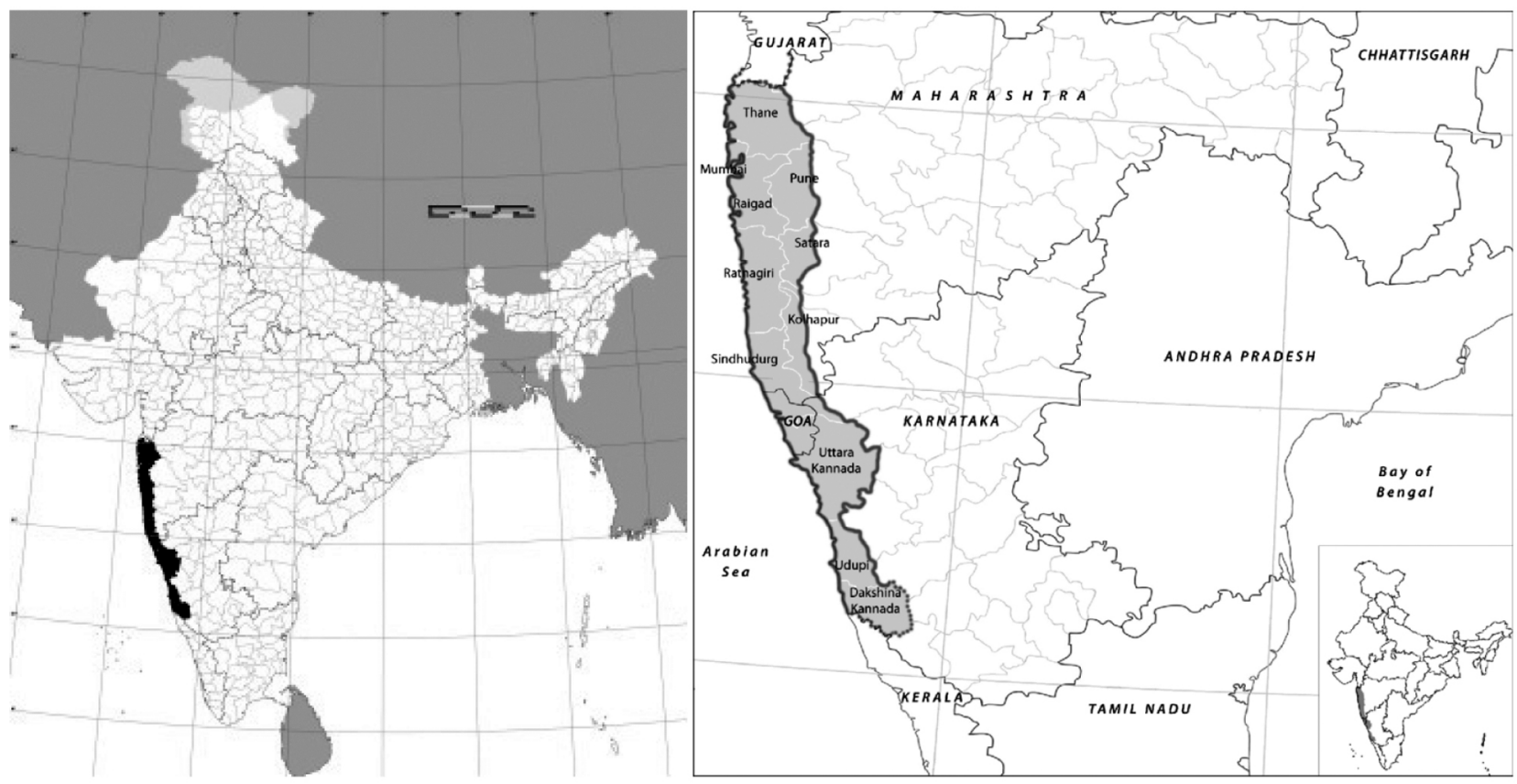

Figure 1. Study location.

2,263,000 ha (ref. 9) and has great potential for carbon sequestration. The area is further expected to increase given the importance given to the horticulture sector in government policies in recent years. This communication reports estimates of carbon sequestration in the Konkan region, one of the major mango belts of India.

Konkan, also known as the Konkan coast, is a part of the Western Ghats having rough terrain. It is a $720 \mathrm{~km}$ long coastline in three the western Indian states, viz. Karnataka, Goa and Maharashtra. The area is lying between $12.8^{\circ} \mathrm{N}, 75^{\circ} \mathrm{E}$ in the south to $19^{\circ} \mathrm{N}, 73^{\circ} \mathrm{E}$ in the north. Konkan region is occupying the land between Arabian Sea and the Western Ghats and between Chandragiri river in the south and the Tapti River in the north (Figure 1). Konkan includes the following districts in the three states: Maharashtra - Sindhudurg, Ratnagiri, Raigad, Mumbai, and Thane; Goa - South and North Goa and Karnataka - Dakshina Kannada, Uttara Kannada and Udupi. The cities of Mumbai and Mangalore form the two end-points of the Konkan coast.

Konkan mango: The famous Alphonso mango is cultivated in the Konkan region on rocky lateritic soils. It is named after Afonso de Albuquerque, a Portuguese general who helped establish colonies in India. This is a typical example of how barren wastelands can be utilized for the promotion of horticulture and to turn hillslopes into mango orchards, thus making them ecologically sustainable, more productive, thereby creating employment for the landless and small and marginal farmers of the Konkan region.

Deforestation in the Konkan region has rendered hillslopes barren and hard rock surfaces remain exposed to heavy rain fall. These lateritic barren surfaces in the Konkan region have become degraded lands and do not fulfil their life-sustaining potential. This has resulted from inherent and imposed disabilities such as by location, environment, chemical and physical properties of the soil, financial or management constraints.

The system of planting Alphonso mango on these exposed, barren laterite rocks (qualifying as wastelands; termed 'Jambhadagad' locally) of the Konkan region, is a successful soil management module developed by local farmers, that has been in practice for several decades ${ }^{10}$. This is a unique model for sustainable development of wastelands with tree-based farming system in the fragile ecosystem of the Western Ghats under heavy rainfall. Today, mangoes grown in the Konkan region carry the GI tag and are marketed as the special 'Haapoos' variety. In fact, farmers from the Konkan districts have established a 'market brand' and have been awarded the Global Good Agricultural Practices (GAP) certificate that enables them to export their mangoes.

The uniqueness of the system lies in bringing such wastelands into a highly sustainable production system. This system has helped establish vegetation in exposed barren laterite rocks in a heavy-rainfall belt and has protected the soil from erosion. It has shown how an entirely harsh-terrain wasteland can be converted into an environmentally, economically and socially accepted sustainable, productive system.

The area under mango in the Konkan region is 106,210 ha (Table 1), of which 1 lakh/hectare area is under Konkan, Maharashtra districts which produce $50,000 \mathrm{mt}$ with an average production of $3.12 \mathrm{t} / \mathrm{ha}$.

CURRENT SCIENCE, VOL. 116, NO. 8, 25 APRIL 2019 
RESEARCH COMMUNICATIONS

Table 1. Area, production and productivity of mangoes in the Konkan region, India

\begin{tabular}{lccc}
\hline Konkan districts & State/Union Territory & Area (ha) & Production (thousand mt) \\
\hline Thane, Mumbai, Raigad, Ratnagiri, Sindhudurg & Maharashtra & 100,000 & 50 \\
North Goa, South Goa & Goa & 4770 & 9.04 \\
Uttara Kannada, Udupi, Dakshina Kannada & Karnataka & 1440 & 4.42 \\
\hline
\end{tabular}

Selection of orchards: The region has fairly uniform cultivation of a single variety of mango called Alphonso. The Portuguese introduced grafting on mango trees in India and thus Alphonso variety was developed from the clones of mango available in the Konkan region. Trees were sampled randomly in the region. In Konkan Maharashtra districts a total of 104 trees of similar age group (25-30 yrs; from Mumbai, Raigad, Ratnagiri and Sindhudurg) were sampled for allometric parameters along with soil and litter samples. Similarly, 75 sample trees from Konkan Goa districts (North and South Goa) and 40 trees from Konkan Karnataka, districts (Udupi, Dakshina Kannada and Uttara Kannada districts) were sampled.

Recording of allometric data: All the orchards selected contained only grafted trees and hence there was no scope for recording the diameter at breast height (DBH), a parameter necessary for using general allometric equation for estimating tree biomass. We followed the allometric equation developed by Ganeshamurthy et al. ${ }^{11}$ for grafted mangoes for estimating the above-ground and belowground tree biomass. The measurement included the number of primary branches and their girth.

Briefly, the allometric equation was developed through the destructive sampling of 74 mango trees covering the age group from 3 to 85 years $(3,5,8,10,12,15,16,20$, 45 and $85 \mathrm{yrs}$ ). Tree parameters suitable for developing allometric equations like basal diameter, diameter below graft union (DBGU), tree volume, tree height, number of primary and secondary branches and their girth were measured from all the 74 randomly selected mango trees of different age groups. The tree height and diameter of the crown were measured with the help of a relascope (Spiegel Relaskop) and stem diameter was measured with a diameter tape.

Statistical modelling: Different statistical nonlinear regression models, like logistic model, Gompertz model and power model were used to estimate tree biomass as the derivatives of $Y_{\mathrm{t}}$ with respect to unknown parameters following a suitable nonlinear estimation procedure for parameter estimation ${ }^{12,13}$. Codes were developed to fit these nonlinear regression models using SAS. Based on the best fit, the power model was used for estimation of tree biomass.

Power model: $Y_{t}=a X_{\mathrm{t}}^{\mathrm{b}}+\varepsilon$.

For below-ground biomass estimation, we followed the ratio of $1: 0.29$, as suggested by Ganeshamurthy et al. ${ }^{11}$.
Tree sampling: Mature leaves were collected from 20 random trees from each orchard for estimation of carbon content. These samples were pooled, washed and dried at $65^{\circ} \mathrm{C}$ in a hot-air oven till constant weight. The samples were powdered for carbon estimation. Similarly, samples of twigs representing tertiary branches and other smaller branches were selected and processed for carbon estimation. The bark and wood samples were collected from selected trees using a tree drill and processed for carbon estimation.

Carbon estimation: Mango tree samples: The carbon content of these samples was estimated using a CHNS analyser (Elementarr) and expressed as percent carbon in the sample.

Weeds and litter: The litter and weed biomass collected from these orchards were processed and analysed for their carbon content using a CHNS analyser (Elementarr) and expressed as percent carbon in the sample.

Soil carbon stock: Representative four pedon samples $(0-15,15-30,30-60$ and $60-100 \mathrm{~cm})$ were collected from the three states in Konkan mango orchards and total carbon stock was estimated in these soils as described below.

Soil samples were collected randomly from ten spots at each depth and mixed thoroughly, and a composite sample was drawn. The samples were air-dried, sieved using a $2 \mathrm{~mm}$ sieve and analysed for total soil organic carbon by Walkley-Black method ${ }^{14}$. The bulk density of soil was determined following core sampling method. Soil bulk density was expressed as the ratio of oven-dry weight of soil core (dried at $105^{\circ} \mathrm{C}$ for $24 \mathrm{~h}$ ) and its total volume. Carbon stock was then calculated as

$$
\text { Carbon stock }=\left(\mathrm{TOC} \times D_{\mathrm{s}} \times e\right) / 10,
$$

where TOC is the total organic carbon at a given soil depth (thickness of the layer); $D_{\mathrm{s}}$ is the soil bulk density at a given soil depth (thickness of the layer) and $e$ is the thickness of the layer.

Mangoes perform better in low-fertility soils and in tropical and subtropical regions ${ }^{15}$. The Konkan region represents a typical tropical hot and humid climate. Soils in the three representative states are lateritic in nature. These lateritic soils are acidic in reaction (Table 2) due to leaching of bases under the influence of heavy rainfall during the six-month monsoon period. The electrical conductivity is very low $\left(<1 \mathrm{dS} \mathrm{m}^{-1}\right)$. Soils are rich in organic matter and hence the bulk density of soils in all 
RESEARCH COMMUNICATIONS

Table 2. Basic soil properties of mango orchards in the Konkan region

\begin{tabular}{|c|c|c|c|c|c|c|c|}
\hline Region & $\mathrm{pH}$ & Org C & $\mathrm{N}$ & $\mathrm{P}$ & $\mathrm{K}$ & Moisture (\%) & Bulk density \\
\hline Konkan Maharashtra & $4.72(4.54-5.16)$ & $1.41(1.03-1.77)$ & $556(453-602)$ & $4.08(3.84-4.22)$ & $296(254-341)$ & $29(24-36)$ & $1.211(1.202-1.218)$ \\
\hline Konkan Goa & $4.61(4.41-4.87)$ & $1.39(1.14-1.68)$ & $460(429-502)$ & $3.55(3.26-3.79)$ & $270(239-292)$ & $33(25-37)$ & $1.276(1.234-1.285)$ \\
\hline Konkan Karnataka & $4.85(4.36-5.28)$ & $1.41(1.23-1.69)$ & $5685(21-620)$ & $3.28(3.04-3.51)$ & $292(257-325)$ & $30(23-39)$ & $1.237(1.209-1.256)$ \\
\hline Mean & 4.73 & 1.40 & 528 & 3.64 & 286 & 30.7 & 1.241 \\
\hline
\end{tabular}

Table 3. Mean allometric parameters and tree carbon sequestered in the Konkan districts

\begin{tabular}{|c|c|c|c|c|c|c|c|c|}
\hline Konkan region & $\begin{array}{c}\text { No. of } \\
\text { primary } \\
\text { branches* }\end{array}$ & $\begin{array}{c}\text { Mean girth } \\
\text { of primary } \\
\text { branches }(\mathrm{cm})^{*}\end{array}$ & $\begin{array}{l}\text { Above-ground } \\
\text { biomass (AGB) } \\
\left(\mathrm{kg} \text { tree }^{-1}\right)\end{array}$ & $\begin{array}{c}\text { AGB } \\
\text { carbon } \\
\left(\mathrm{kg} \mathrm{tree}^{-1}\right)\end{array}$ & $\begin{array}{l}\text { Below-ground } \\
\text { biomass (BGB) } \\
\left(\mathrm{kg} \mathrm{tree}^{-1}\right)\end{array}$ & $\begin{array}{c}\text { BGB } \\
\text { carbon } \\
\left(\mathrm{kg} \mathrm{tree}^{-1}\right)\end{array}$ & $\begin{array}{c}\text { Total } \\
\text { carbon } \\
\left(\mathrm{kg} \mathrm{tree}^{-1}\right)\end{array}$ & $\begin{array}{l}\text { Total } \\
\text { carbon } \\
\left(\mathrm{t} \mathrm{ha}^{-1}\right)\end{array}$ \\
\hline Maharashtra & 3.26 & 56.00 & 382.13 & 229.28 & 115.25 & 70.92 & 300.20 & 30.02 \\
\hline Goa & 3.11 & 43.84 & 328.69 & 197.22 & 99.13 & 61.01 & 258.22 & 25.822 \\
\hline Karnataka & 3.32 & 46.7 & 316.7 & 190.0 & 122.4 & 58.8 & 248.8 & 24.88 \\
\hline Mean & 3.23 & 48.85 & 342.51 & 205.5 & 112.26 & 63.58 & 269.07 & 26.91 \\
\hline
\end{tabular}

*Mean of 100 trees.

the three states is low. The available nitrogen content is high, phosphorus is low and potassium is medium. The available phosphorus is low because fixation of $\mathrm{P}$ by lateritic soils is higher due to higher sesquioxides in these soils. Earlier reports have also described similar properties of lateritic soils from Konkan Maharashtra ${ }^{16}$, Karnataka and Goa ${ }^{17}$.

Carbon storage from a mango tree is estimated based on dry matter and $\mathrm{C}$ content of the tree parts. The average number of primary branches observed was 3.26 in Konkan Maharashtra, 3.11 in Konkan Goa and 3.32 in Konkan Karnataka, with an overall mean of 3.23 (Table 3). The mean girth of primary branches was $56.0 \mathrm{~cm}$ in Konkan Maharashtra, $43.84 \mathrm{~cm}$ in Konkan Goa and $46.7 \mathrm{~cm}$ in Konkan Karnataka, with an overall mean of $48.85 \mathrm{~cm}$. This showed that trees in Konkan Maharashtra are more robust than those in other two states. Utilizing these two parameters the above-ground biomass of mango trees was estimated following the allometric equation developed for grafted mangoes by Ganeshamurthy et al. ${ }^{11}$. On per tree basis the above-ground biomass was more in Konkan Maharashtra (382.13 $\left.\mathrm{kg}^{-1} \mathrm{tre}^{-1}\right)$ followed by Konkan Goa $\left(316.7 \mathrm{~kg} \mathrm{tree}^{-1}\right)$ and Konkan Karnataka $\left(342.51 \mathrm{~kg} \mathrm{tree}^{-1}\right)$. The above-ground biomass was far less than that of ungrafted polyembryonic mango trees grown wild in forests and in isolated places in farmer's fields and avenues which have a tree diameter as large as $200 \mathrm{~cm}$ (refs 18, 19). Similarly, the below-ground biomass was estimated using the root-to-shoot ratio of 0.29 recommended by Ganeshamurthy et $a .^{11}$. The below-ground biomass also followed a similar trend as of above-ground biomass. Utilizing the mean carbon content of the above- and below-ground biomass, the total above-ground and below-ground carbon sequestered by grafted mangoes was estimated. The total tree carbon sequestered varied from $248.8 \mathrm{~kg}^{-1}$ tree ${ }^{-1}$ in Konkan Karnataka to $300.2 \mathrm{~kg}^{-1} \mathrm{tree}^{-1}$ in Konkan Maharashtra. This is far below the values reported for polyembryonic wild mango trees ${ }^{19}$ as the grafted mangoes are dwarf-like, planted close and the canopy is regularly managed to maintain short stature of the tree for convenience.

Weeds and litter represent the floor-level carbon sequestration. The annual weed biomass was estimated using samples collected from 100 orchards in Konkan Maharashtra, 75 in Konkan Goa and 40 in Konkan Karnataka. Orchards in Konkan Karnataka had higher weed biomass and hence captured higher carbon followed by Konkan Maharashtra and Konkan Goa (Table 4). This is because general management of mango orchards is better in Konkan Maharashtra than in the other two regions. This is reflected on the weed biomass and carbon capture through weeds in the three regions. However, litter biomass was more in Konkan Maharashtra followed by Konkan Goa and Konkan Karnataka. This depends more on tree growth and fruiting behaviour. Konkan Maharashtra tree yields are generally better than those of the other two regions. This is reflected on litter biomass and carbon capture through litter.

The proportion of this fraction of weeds and litter in total carbon sequestration is very low. Generally, in forests, the floor carbon represents less than $10 \%$ of the total carbon sequestered $(\mathrm{CS})^{20}$. This is highly variable in fruit orchards as it depends upon the management followed in different orchards. If weeding is practised regularly, the fraction of this carbon will be low. In the present study, weed and litter biomass represent $13.6 \%$ of total CS in Konkan Maharashtra, 15.1 in Konkan Goa and 15.9 in Konkan Karnataka, with a mean of $14.8 \%$. This shows that Maharashtra farmers control weeds in the orchard floor better than those in the other two regions. The contribution of litter to total carbon sequestered is low, but its role in the carbon biogeochemical cycle is important as it acts as an interface between carbon in soil and in vegetation. 
RESEARCH COMMUNICATIONS

Table 4. Litter and weed biomass carbon in the Konkan mango orchards

\begin{tabular}{|c|c|c|c|c|c|c|c|}
\hline Region & $\begin{array}{c}\text { Weed } \\
\text { biomass } \\
(\mathrm{kg} / \mathrm{ha})\end{array}$ & $\begin{array}{c}\% \text { Mean } \\
\text { carbon content }\end{array}$ & $\begin{array}{l}\text { Weed carbon } \\
(\mathrm{kg} / \mathrm{ha})\end{array}$ & $\begin{array}{l}\text { Litter biomass } \\
\qquad(\mathrm{kg} / \mathrm{ha})\end{array}$ & $\begin{array}{l}\% \text { Mean litter } \\
\text { carbon content }\end{array}$ & $\begin{array}{c}\text { Litter } \\
\text { carbon } \\
(\mathrm{kg} / \mathrm{ha})\end{array}$ & $\begin{array}{c}\text { Total carbon } \\
\text { content } \\
\left(\mathrm{t} \mathrm{ha}^{-1}\right)\end{array}$ \\
\hline Konkan Maharashtra & 492 & 45.8 & 225.33 & 1360 & 46.3 & 629.68 & 0.855 \\
\hline Konkan Goa & 476 & 46.5 & 221.34 & 1304 & 45.7 & 595.92 & 0.817 \\
\hline Konkan Karnataka & 524 & 44.3 & 232.13 & 1266 & 47.2 & 578.67 & 0.811 \\
\hline Mean & 497.3 & 45.5 & 226.26 & 1310 & 46.4 & 601.42 & 0.828 \\
\hline
\end{tabular}

Table 5. Soil carbon in mango orchards of the Konkan region

\begin{tabular}{lc}
\hline Region & Soil C (t/ha) \\
\hline Konkan Maharashtra & 63.8 \\
Konkan Goa & 64.5 \\
Konkan Karnataka & 60.5 \\
& 62.9 \\
\hline
\end{tabular}

Soil carbon equilibrium depends upon land-use systems. A quasi-equilibrium of soil organic carbon is attained over a long period of accumulation and loss. The equilibrium shifts after each disturbance in the land-use pattern resulting from tooth-like cycles of accumulation and loss. The stabilization of soil carbon levels depends upon the period of constant management. Hence a quasiequilibrium value is attained after each change in the land-use pattern. In this way, the soil organic carbon (SOC) is stabilized to other new quasi-equilibrium values of the changed situation in terms of new land-use patterns, vegetation cover and management practices. A forest system attains quasi-equilibrium value in 500-1000 years, whereas it takes only 30-50 years in agricultural systems after clear-felling of the forest. It may take 30 years for a horticultural system ${ }^{21}$. Our experience shows that perennial horticultural systems under these tropical land-use patterns attains quasi-equilibrium value in 25 years $^{22}$.

Mango is being grown in the three Konkan regions since about 100 years. Hence soils under these mango orchards in the three regions have attained quasiequilibrium stage after the accumulation of dry matter and loss of SOC over time. The soil carbon stocks in the three Konkan regions vary from 60.5 to $64.5 \mathrm{t} / \mathrm{ha}$ (Table 5). Highest carbon stock was recorded in Konkan Goa followed by Konkan Maharashtra and the least in Konkan Karnataka.

The proportion of soil carbon in total carbon sequestered in the Konkan mango orchards is higher than the tree carbon. It has been shown that the proportion of soil carbon in many instances exceeds the tree biomass carbon $^{23}$. In the present study, the proportion of soil carbon to the total sequestered $\mathrm{C}$ is $65.48 \%$ in Konkan Maharashtra, $68.73 \%$ in Konkan Goa and $68.0 \%$ in Konkan Karnataka, with a mean of $67.39 \%$. Gupta ${ }^{24}$ reported that in mango orchards in Mangalore, the soil carbon stocks was $41 \mathrm{t} /$ ha in the surface $50 \mathrm{~cm}$ depth. Chhabra et al. ${ }^{25}$ have also reported that the soil carbon sequestered in Indian forests ranged from $37.5 \mathrm{t} / \mathrm{ha}$ in tropical dry deciduous forests to $92.1 \mathrm{t} / \mathrm{ha}$ in littoral swamp forests. The values reported in the present study are for $100 \mathrm{~cm}$ depth soil profiles; these fairly similar to the values reported in the study for the Konkan region representing the same climate.

Table 6 gives the carbon pool compartment of mango orchards. The mean carbon sequestered in mango orchards varies from $88.97 \mathrm{t} / \mathrm{ha}$ in Konkan Karnataka to 97.43 t/ha in Konkan Maharashtra. This is very low compared to wild polyembryonic mango trees grown from seeds. The reason is that wild mango trees may reach $40 \mathrm{~m}$ or more in height and live for several hundred years as against $8-10 \mathrm{~m}$ height and lifespan of 40-50 years in cultivated grafted mangoes. Wild mangoes are fastgrowing, erect trees with slender to broad and rounded, upright canopy. On the other hand, grafted mangoes are dwarf-like, have relatively slow growth and are branched at the surface. The wild trees are long-lived with some still producing fruits even when 300 years old. Whereas the orchard trees generally shows a decline in yield after 30 years. The wood density of wild mangoes is relatively higher (specific gravity 0.68$)^{26}$ than cultivated mangoes (specific gravity $0.52-0.55$ ). The tree is anchored by a long unbranched taproot and can descend to greater depths plus a mass of feeder roots as against a narrow root volume of grafted mangoes. The feeder roots of wild mangoes send down anchor roots which penetrate the soil to a depth of $1.2 \mathrm{~m}$ and spread laterally as far as $7.5 \mathrm{~m}$ as against less than $1 \mathrm{~m}$ depth and a spread of $2-3 \mathrm{~m}$ in grafted mangoes. All these parameters show that biomass productivity of grafted mangoes is far lower than wild mangoes.

The regional carbon sequestration by orchard mangoes in the Konkan area was computed by multiplying the per hectare carbon sequestration by orchard mangoes with the regional area under mango cultivation (Table 7). Konkan Maharashtra having the maximum area under mangoes has sequestered $9.743 \mathrm{mt}$ of carbon. This is followed by Konkan Goa $(0.448 \mathrm{mt})$ and Konkan Karnataka $(0.128 \mathrm{mt})$. The region as a whole has sequestered $9.912 \mathrm{mt}$ of carbon in its mango orchards.

It is essential to understand the land-use/land-change dynamics in a given region and changes in carbon flux 
RESEARCH COMMUNICATIONS

Table 6. Carbon pool compartment $\left(\mathrm{t} \mathrm{ha}^{-1}\right)$ in the Konkan mango orchards

\begin{tabular}{llcccccc}
\hline Konkan region & $\begin{array}{c}\text { ABG } \\
\text { tree C }\end{array}$ & Litter C & Weed C & $\begin{array}{c}\text { Total above } \\
\text { ground C }\end{array}$ & Root C & $\begin{array}{c}\text { Soil C } \\
\text { ground C }\end{array}$ \\
\hline Maharashtra & 22.928 & 1.360 & 2.253 & 26.541 & 7.092 & 63.8 & 70.892 \\
Goa & 19.722 & 1.304 & 2.213 & 23.239 & 6.101 & 64.5 & 70.601 \\
Karnataka & 19.00 & 1.266 & 2.321 & 22.587 & 5.880 & 60.5 & 66.38 \\
Mean & 20.55 & 1.310 & 2.263 & 24.123 & 6.358 & 62.9 & 69.210 \\
\hline
\end{tabular}

Table 7. Carbon sequestered in the Konkan mango orchards

\begin{tabular}{lrrr}
\hline Konkan region & Area (ha) & Total C sequestered in 1 ha orchard $\left(\mathrm{t} \mathrm{ha}^{-1}\right)$ & Total C sequestered in the region $((000) \mathrm{t})$ \\
\hline Maharashtra & 100,000 & 97.433 & $9,743.3$ \\
Goa & 4770 & 93.84 & 447.62 \\
Karnataka & 1440 & 88.967 & 128.11 \\
Total & 106,210 & 93.333 & $9,912.90$ \\
\hline
\end{tabular}

derived from such land-use change patterns to formulate a viable strategy for climate change mitigation. We must therefore, obtain regional-level basic information on carbon content associated with various stocks of natural and man-made land-use/land-change classes. The present study involved in integration of different methodologies for field-work and data processing. The study generated unique information, both in terms of stocks and on allometric equations for grafted mangoes. It is thus a valuable first step for advancing our knowledge of the carbon cycle in cultivated mango ecosystems. Future efforts should consider mango orchards in other regions of India and with larger sample size, to determine carbon sequestered in cultivated mango orchards in the country as a whole.

The mangoes in the Konkan region have mostly occupied degraded lands of lateritic origin. Maharashtra itself has about $17 \%$ of the Konkan region as wastelands. This is the region which occupies the famous Alphonso mangoes. Similarly, in Konkan Goa and Konkan Karnataka also, mangoes occupy similar soils. Such regions are brought under productive mango orchards. As a consequence where forests have disappeared and mangoes have occupied the region, the carbon sequestered by these fruits is a bonus apart from the production of mangoes. The administrators in these regions must use this information to claim carbon credits for the benefit of farmers and the local population.

1. Achard, F., Eva, H. D., Stibig, H. J., Mayaux, P., Gallego, J., Richards, T. and Malingreau, J. P., Determination of deforestation rates of the world's humid tropical forests. Science, 2002, 297, 999-1002.

2. Fearnside, P. M. and Laurance, W. F., Tropical deforestation and greenhouse gas emissions. Ecol. Appl., 2004, 14(4), 982-986.

3. Gitay, H. et al., Ecosystems and their services. In Impacts, Adaptation and Vulnerability to Climate Change. Third Assessment Report of the Intergovernmental Panel on Climate Change, Cambridge University Press, 2001, pp. 236-342.
4. Houghton, R. A., Revised estimates of the annual net flux of carbon to the atmosphere from changes in land use and land management 1850-2000. Tellus, 2003, 55, 378-390.

5. Hudson, J. M., Gherini, S. A. and Goldstain, R. A., Modelling the global carbon cycle: $\mathrm{N}$ fertilization of the terrestrial of the biosphere and the 'missing' $\mathrm{CO}_{2}$ sink. Global Biogeocycles, 1994, 8, 307-333.

6. Arulselvi, G., Ramalingam, V. and Palanivel, S., Analysis of carbon sequestration pattern in tropical fruit trees. Int. J. Comput. Appl., 2011, 30(7), 24-29.

7. Dadhwal, V. K., Pandya, N. and Vora, A. B., Carbon cycle for Indian forest ecosystem: a preliminary estimate. In Global Change Studies: Scientific Results from ISRO-GBP (eds Subbaraya, B. H. et al.), ISRO, Bengaluru, 1998, pp. 411-430.

8. Ravindranath, N. H., Somshekhar, B. S. and Gadgil, M., Carbon flows in Indian forests. Climate Change, 1997, 35, 297-320.

9. Horticultural Statistics at a Glance, National Horticulture Board and Horticulture Statistics Division Department of Agriculture, Cooperation and Farmers' Welfare, Ministry of Agriculture and Farmers' Welfare, Government of India.

10. Ganeshamurthy, A. N., Eleven models of sustainable soil management in horticultural systems. IIHR, Technical Bulletin. 2015, p. 44.

11. Ganeshamurthy, A. N., Ravindra, V., Venugopalan, R., Malarvizhi Mathiazhagan and Bhatt, R. M., Biomass distribution and development of allometric equations for non-destructive estimation of carbon sequestration in grafted mango trees. J. Agric. Sci., $2016,8,201-211$.

12. Seber, G. A. F. and Wild, C. J., Nonlinear Regression, John Wiley, NY, USA, 1989; doi:10.1002/0471725315.

13. Venugopalan, R. and Shamasundaran, K. S., Nonlinear regressions: a realistic modeling approach in horticultural crop research. J. Indian Soc. Agric. Stat., 2003, 56, 1-6.

14. Nelson, D. W. and Sommers, L. E., Total carbon, organic carbon and organic matter. In Methods of Soil Analysis: Chemical Methods. Part 3 (ed. Sparks, D. L.), Soil Science Society of America, Madison, WI, USA, 1996, pp. 61-1010.

15. Ganeshamurthy, A. N. and Reddy, Y. T. N., Fitness of mango for colonization in low fertility soils and dry lands: examination of leaf life-span, leaf nutrient resorption, and nutrient use efficiency in elite mango varieties. Agric. Res., 2015, 4(3), 254-260.

16. Borkar, V. S., Gokhale, N. B., Dhopavkarm, R. V., Khobragade, N. H., More, S. S. and Kasture, M. C., Distribution of nutrients in different soil types in Konkan region of Maharashtra. Int. J. Chem. Stud., 2018, 6(1), 275-279. 


\section{RESEARCH COMMUNICATIONS}

17. Shinde, S. B., Physico-chemical properties of lateritic soil from mango orchards in Ratnagiri and Sindhudurg districts. M Sc (Agric) thesis, Dr Balasaheb Sawant Konkan Krishi Vidyapeet, Dapoli, 2006.

18. Selvaraj, A., Jayachandran, S., Thirunavukkarasu, D. P., Jayaraman, A. and Karuppan, P., Carbon sequestration potential, physicochemical and microbiological properties of selected treesMangifera indica L., Manilkara zapota L., Cocos nucifera L. and Tectona grandis L. Biosci. Discov., 2016, 7(2), 131-139.

19. Eneji, I. S., Obinna, O. and Azua, E. T., Sequestration and carbon storage potential of tropical forest reserve and tree species located within Benue State of Nigeria. J. Geosci. Environ. Prot., 2014, 2, $157-166$.

20. Usuga, J. C. L., Toro, J. A. R., Alzate, M. V. R. and Tapias, Á. J. L., Estimation of biomass and carbon stocks in plants, soil and forest floor in different tropical forests. For. Ecol. Manage., 2010 260(10), 1906-1913.

21. Chandran, P., Ray, S. K., Durge, S. L., Raja, P., Nimkar, A. M., Bhattacharyya, T. and Pal, D. K., Scope of horticultural land-use system in enhancing carbon sequestration in ferruginous soils of the semi-arid tropics. Curr. Sci., 2009, 97(7), 1039-1046.
22. Ganeshamurthy, A. N., Annual Report, Indian Institute of Horticultural Research (IIHR), Bengaluru, 2012.

23. Ordo'ñez, J. A. B. et al., Carbon content in vegetation, litter, and soil under 10 different land-use and land-cover classes in the Central Highlands of Michoacan, Mexico. For. Ecol. Manage., 2008, 255, 2074-2084.

24. Gupta, M. K., Soil organic carbon pools under different land use in Haridwar district of Uttarakhand. Indian For., 2011, 137(1), 1-8.

25. Chhabra, A., Palria, S. and Dadhwal, A. K., Soil organic carbon pools in Indian forests. For. Ecol. Manage., 2003, 173, 187-199.

26. Wood database-Mango. 2018; http://www.wood-database.com/ mango/

ACKNOWLEDGEMENT. The financial support for this study received from the Indian Council of Agriculture Research-National Innovations on Climate Resilient Agriculture is gratefully acknowledged.

Received 8 June 2018; revised accepted 25 January 2019

doi: $10.18520 / \mathrm{cs} / \mathrm{v} 116 / \mathrm{i} / 1417-1423$ 